\author{
Wang Yan, \\ Changchun Normal University, Changchun, China \\ (iD) ORCID ID, 0000-0001-7221-6941 \\ email: mr.wang.yan.90@gmail.com
}

Correspondence author: mr.wang.yan.90@gmail.com

\title{
OLYMPIC GAMES AS A DIGITAL MEDIA PRODUCT
}

Abstract. This paper studies the development of economic ties between professional sports and media in the past ten years by the example of the Olympic Games media coverage. The main purpose of the research is to identify the regularities that are formed in the communicative environment of elite sports. The paper is focused on the Olympic Games as the global sports events that include several types of sports competitions. The subject of the study is the sport as a product. The object of the study is the sport entertainment products in the media sphere. The relevance of the research is that the interconnections between sports and media expand and change rapidly and are influenced not only by the development of new technologies but also by a coronavirus situation. The systematization of literary sources on the selected matter indicated the need for further studies to reflect the rampant evolution of sports media and the lack of unified terminology for viewing professional sports through the prism of mass media as a media product. The methodology of the research is based on the analysis of open-source statistical data and a set of empirical materials (official websites of sports organizations, TV channels, and social media pages). The author viewed these materials from four perspectives: the audience, the marketing approach, the sports themselves as a source of information, the mainstream and the new media. The results allowed identifying the main trends of the information space formation around the object under study. These trends prove that the structure of the "Elite Sports» media product is becoming more complex, and the number of communicative links and broadcasting opportunities of sports events has increased. Finally, the author proposed a conceptual model of representing professional sports as a media product on the example of the major sports events, through defining its communication links. The findings of the research could be useful for setting vectors for studying mainstream and new media in the chosen area. The study can be of interest to sports journalists, bloggers, managers, and officials.

Keywords: audience, communication, content distribution, professional sports, sports event.

Introduction. A stadium lease agreement, monopolistic negotiations on broadcasting rights, territorial rights in predefined geographical markets and amortization of player's capital, etc. differ professional sports from other types of businesses. Perhaps the most noticeable difference that sport has is in the relationship with the consumers. The phenomenon of great attention to sports in various cultures and societies explain best the reality and unpredictability of this entertainment: «Titanic always sinks! The outcome uncertainty of sports keeps spectators on their toes permanently» (Beech and Chadwick, 2010).

Sports events and competitions provide several functions in human society. For some people watching sports, competition is a kind of sublimation of their desires about sport achievement or just inability, due to some circumstances, to be involved in more or less professional sport. Secondly being on a stadium or a game field, observing a game on TV or the Internet, etc. a person has so-called partner feeling (the involvement in success and a particular social group) with the rest of the people who support the same team or sportspeople. Such activities as a tote for win or loss have always been presented during the long period holding sports events. That also keeps people's interest in the sport. All these factors make sport to be a unique media product (Goodyear et al., 2018). The interaction of sports and media is an obviously important criterion of the popularization of a certain sport or sports event, growth of its audience. Therefore, forming appropriate relations are beneficial for sports federations, leagues, organizing committees, etc. (Pilar et al., 2019). The growing number and capabilities of modern communications change the

Cite as: Yan, W. (2020). Olympic Games as a Digital Media Product. Marketing and Management of Innovations, 3, 306-318. http://doi.org/10.21272/mmi.2020.3-22 
regularities of information distribution, complicate links, fade-out spatial borders, and expand areas of influence. In the conditions of the digital reality, the publicity of professional sports, being the area of our focus, raises manifold. Modern people obtain much information through mainstream and new media, which form personal and public opinions, influence political decisions, shape cultural values, build social communication links, and as a result, change people's daily life (Mauro, 2020). The elite sports are closely associated with the media and be under its spotlight, as they are a replicated type of professional activity, popular among the audience and possessing a huge business capacity. Thus, we consider professional sports through the prism of mass media as a media product. Due to the lack of unified terminology, it should note that we interpret this marketing term as a single system, a synthesis of information content and means of its distribution (Reca, 2006). The study aimed to find out the interconnections and relations of the sports with the mass media, new technologies and the consumers (the audience) ad to find out which means are the most suitable for the professional sports events to be sold and widely spread as a business product. The subject of the study is the sport as a product, and the object of the study is the sport entertainment products in the media sphere.

Nowadays, not only the new technologies influence the mass media and the products they present to the audience. The situation with coronavirus should make mass media investors and producers think about how to present the sports events as a media product in the new circumstances. With the absence of the audience on the stadium, new technologies should serve the way that the viewers will not miss a thing and feel being present on an event as the interactive participants. For the media sector, the coronavirus creates opportunities. Social distancing has led to a dramatic increase in media consumption in the home, and more people are turning to news providers for timely and reliable information.

Literature Review. Most civilizations had sports activities of an elementary nature: running, boxing, fight, horse racing, throwing a javelin, disk, stone, archery, and swimming, etc. Unsurprisingly, today's players and fans still find the sport very attractive. The development of sports from prehistoric times to the present is a function of industrialization, modernization, and telecommunications. Sports support social and cultural identities and the creation of national identities (Brown and O'Rourke III, 2003). Mass media makes sports not only an important public issue, but with the help of entertaining components, it sells them (Bryant and Raney, 2000). The press is the oldest mass media that regularly informs people about sports events. The sports teams have shown great interest in print media: newspapers and magazines have formed the primary way of communicating upcoming events and the results of past events. News of upcoming events created audiences for sporting events and, along with past events, helped sell newspapers. With the era of electronic media, especially television, the functions of the sports press have changed. Other media could report the results and progress of a match or race much faster than newspapers and magazines. On-air reporting on radio and television increase the general interest in the sport. Still, due to lack of time, television and radio reporters are unable to provide sufficient background information. While television remains the leading sporting tool, daily sports sections in newspapers are also very popular, especially among the young audience (Steen, 2013; Carriedo et al., 2019).

On-air radio broadcast gave the feeling of being there and evidence of something emotional. Broadcasters learned very quickly how to create the impression of dense and dramatic events. The biggest advantage of the radio was and remained its very high speed. Results and scores can be instantly distributed. The radio media can reach people anytime and anywhere, for example, in a car, workplace, home, etc. Technically, radio stations and their reporters can be very easily linked so that radio audiences can leave one place for another virtually. Finally, radio coverage trumps interviews, one of the authentic genres of radio (Smith, 2001).

Television has become the leading mass media in the context of sports. With the help of television, viewers can watch sporting events from their own homes. Close-ups, replays, slow motion, different angles from different cameras, and cameras that follow the action are the bonuses of TV media. Combining tools 
of the show with the competition, TV has even created its sport. Sports, media, and advertising create a very popular service: sports show business. Television maintains, popularizes and dominates sports. It leads to the globalization of sports. Athletes and their managers are ready to receive interference from the television to advertise them (Gabaston and Leconte, 2000; Pedersen et al., 2017). Since the middle of 1990s, the Internet started to broadcast live sports events. Statistics, plans, and background information can be viewed without any problem due to the almost unlimited memory capacity of the Web. Thus, the new media can be used as a sports encyclopedia. The Internet is a platform on which athletes can speak and promote themselves: almost all sports clubs and successful athletes have their own websites. Finally, the World Web is an interactive environment, so sports enthusiasts can also act as web publishers but not only the viewers. Websites are relatively easy to create and use. With the help of a search engine, fans can easily find even detailed information on special topics. Thus, the Internet is also an ideal place for sports information, and for those sports that are neglected in other media (Bieber and Hebecker, 2000). The rise of various social sports networks in modern society allows journalists from different media groups to publish information assiduously. In this way, they can directly contact consumers and have greater influence (Devlin and Brown, 2017; English, 2017). As soon as the mass media have big audiences, they have become to be tools for the sport and political aims. It concerns mainly professional and popular kinds of sport, including the Olympic Games. In this situation, the Olympic Games promote sports that are out of the mass attention. With the help of mass media, sport and economy can create a good working tandem: the advertisers send their messages to the viewers, and the organizers can earn a lot of money, and the sportsmen can get higher salaries. The mass media also get their bonus by creating attractive programs (Lenskyj, 2000; Goldblatt, 2018). On the other hand, sports events produce some problems for mass media companies. Exclusive rights for translation make it hard to recoup television station expenses because of the high prices. For covering these expenses, a TV program should include lots of advertising, but numerous interruptions make a program lose its attractiveness for the audiences. Even pay-tv channels cannot compete in this area as there are many free ones. Poor sports season creates the risk for mass media companies decreasing the number of spectators and as a consequence reducing the price for the advertising (Beech, 2007).

Methodology and research methods. When considering professional sports as a media product, one should consider the cross-disciplinary and multifaceted nature of possible approaches. In our opinion, the study can be conducted from the following four perspectives:

1) the audience (fans and fan communities) is the main factor;

2) the marketing approach that assumes a detailed consideration of the commercial interests of all stakeholders, from individual athletes to corporations;

3) sports themselves as a source of information are the core of the research activity;

4) the mainstream and new media are at the periphery of the research activity.

The provided list is by no means limited to the above. For example, in certain countries, including China, the USA, Russia, etc., the government is involved as the extra «player», benefiting from hosting and broadcasting high-profile sports events. Besides, the interests of the above "players» can tightly interweave, acquiring new forms, evolving, and generating previously unknown study areas.

Without focusing on any of the mentioned areas and abstracting ourselves from the legal aspects of the right broadcast acquisition, commercial and public interests, we tried to compile an overall picture of the information saturation and communications, substantiating the identified trends with specific examples and facts. The research methodology includes observation, content analysis, benchmarking, systematic approach, and methods of visualization, simulation, and forecasting.

The sources of practical data for this research included a large scope of materials, such as TV broadcasts, video archives, and text files. A major part of the information was taken from:

- $\quad$ official websites of sports organizations (IOC, FIS, IBU, ISU, IOF); 
- $\quad$ official websites of TV channels (Sky Sports, CCTV-5);

- $\quad$ the statistics and business analytics portal www.statista.com;

- $\quad$ social media (Twitter, Facebook, Instagram, YouTube, Weibo).

We also used the theoretical base provided in marketing, sociology, and mass communication publications (Reca, 2006; Boykoff, 2018; Grenz and Eisewicht, 2017).

Results. Sport is considered an integral part of human culture and a powerful educational and moral resource. But besides it the sport is an industry, a set of segments of the economy focused on a sports and entertainment product, the main participants of which are the sportsmen. It is the unpredictability of the results that makes sports so attractive to the consumers and to the sports industry in general, and it is the main characteristic of a sports product that is sold (directly or indirectly) by the professional sportsmen and the teams to the spectators. The entertainment of a sports product is determined not only by its aesthetics (the beauty and brightness of the sportsmen' performance or the game of a sports team). It also defined by the ability to retain the consumer attention to the sports product (spectator) until the end of a sporting event within which a sports product is produced. Moreover, it is by the ability to keep the spectator in suspense up to a certain point. The Olympic Games is one of the few ways to show the power and strength of the country positively and peacefully, and for some countries, it is the just one way to declare their existence. The choice of the Winter Olympic Games as a sporting event has been caused by the fact that in winter when the Games are held, most of the people travel less and due to the weather spend more time at home watching TV and online broadcast. It means that during this period, it is easier to follow the quality and quantity of the audience. At the same time in the work, there are represented materials on the Summer Olympic Games as well. These two global sports events have also been chosen as they include many sports competitions of different kinds, and each of them has a audience.

The Summer Olympic Games supposed to be in Japan in 2020, but the world situation with coronavirus changed the situation. With the threat of recurrence of the world pandemic internet and TV translation of the sports events and Olympic Games will be the only possibility for the audiences to observe the sport product and for the mass media to sell the entertainment sport product. The conceptual model of professional sports representation as a media product will be able to test during the next Olympic Games. That is why the model has been developed on the information mostly connected with the Winter Games.

Winter Olympic Games. Anticipating the 2022 Beijing Olympics, we, first, studied the statistics of the previous Winter Olympics and noticed an emergent decline in TV viewers' interest to this global sports event (Figure 1). The statistical data was provided by the German online portal Statista that makes data by collecting market and opinion researches and economic sector.

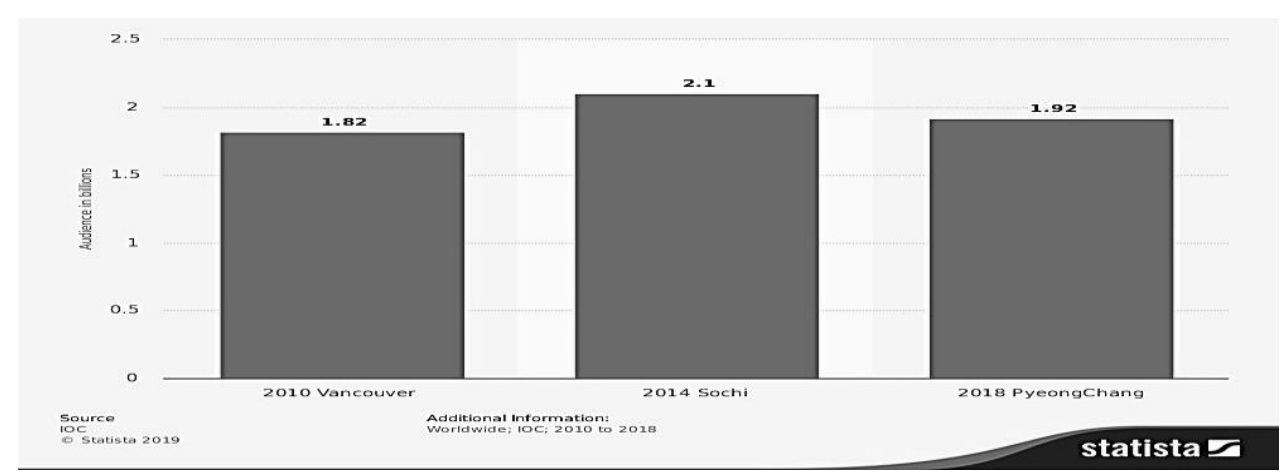

Figure 1. Winter Olympic Games global TV audience in 2010-2018 (billions)

Source: developed by the authors based on (Statista, 2019a). 
The statistics show the global Winter Olympics audience from 2010 to 2018. The aggregate audience was estimated by the total number of times each viewer around the world tuned to Olympic TV programs. It should mention that sociologists have been recently criticizing the Olympic Movement, raising the eternal questions of race and gender stereotypes, as well as the economic rationale of the Olympics for the hosting country; drawing the attention to the loss of IOC's credibility, etc. This critical attitude is carried over to the general public (Boykoff, 2018), which logically should affect the overall popularity of the Olympics and is consistent with the statistics shown in Figure 1. The IOC's response to the emerged situation is reflected in the advance advertising of the 2022 Beijing Olympics, which mentions adding new spectacular events, such as mono-bob and freestyle, as well as various dynamic mixed team contests. Gender equality is emphasized as well: «The 2022 Beijing Olympics will host more female athletes and women's contests compared to any other Winter Olympics, with the share of women raised from $41 \%$ to $45.44 \%$ » (Olympic Games. Future games sports, 2018). We would also like to mention that the TV format sets specific requirements for broadcasting events and they keep being complied with currently. For example, the costly broadcasting time is shortened for biathlon by reducing the track length for individual contests, and the quickest super sprints are added (Biathlon World, 2018) to shorten the airtime and add liveliness. On the other hand, such an event as ski orienteering (IOF official site, n.d.) gains a chance to be included in the Olympics' program in the future thanks to the GPS. The major problem of ski orienteering was the lack of audience appeal and a possibility for the TV to approach checkpoint search areas. Currently, due to the introduction of GPS tracking, viewers are able to watch forest events online. Marking the overall orientation to the young audience as mentioned above, the review on the statistics of online sports event streaming allowed noticing a stable growth of the number of its followers (Figure 2).

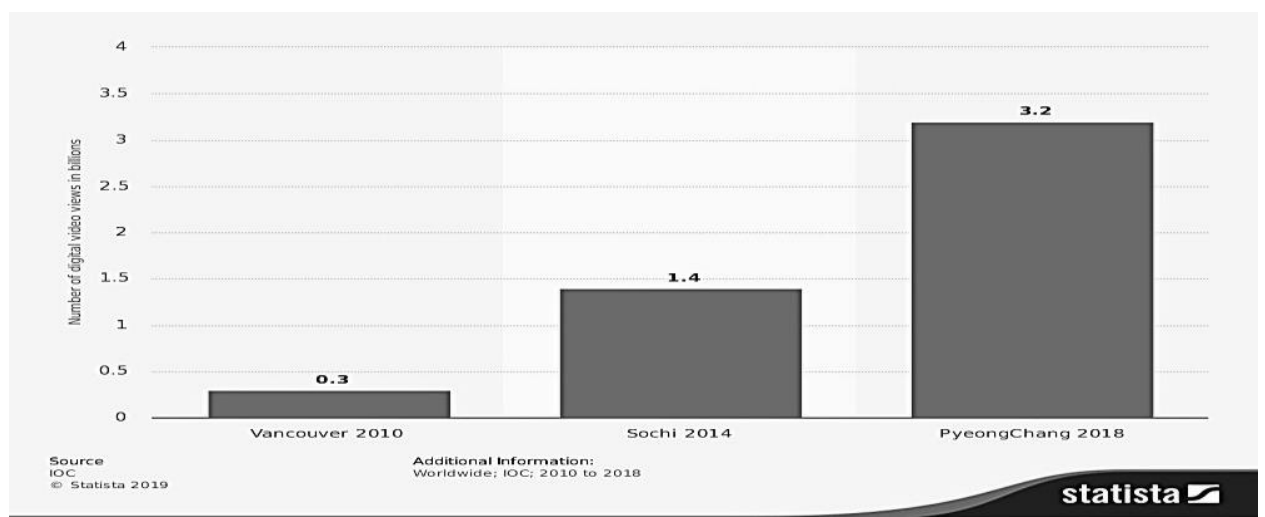

Figure 2. Winter Olympic Games number of digital video views worldwide in 2010-2018 (billions)

Source: developed by the authors based on (Statista, 2019b).

The statistics show the total number of online streaming views during the Winter Olympics between 2010 and 2018. Undoubtedly, such a pronounced growth, 1.8 billion for four years, is the first of all due to the accessibility of technical devices to modern people.

Summer Olympic Games. The TV audience statistics of the Summer Olympic Games from 2008 to 2016 shows the reduction of the TV audience (Figure 3). 


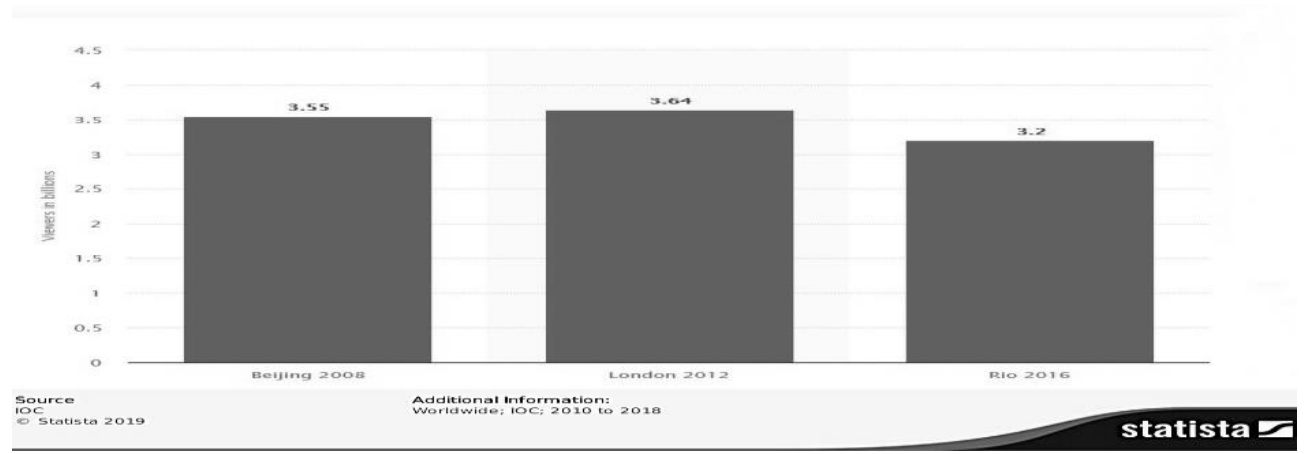

Figure 3. The TV audience of the Summer Olympic Games from 2008 to 2016 (billions)

Source: developed by the authors based on (Statista, 2019c).

The reduction of the TV audience does not mean the lack of interest in The Olympic Games. Figure 4 demonstrates the growth of the video streams from the Olympic Games.

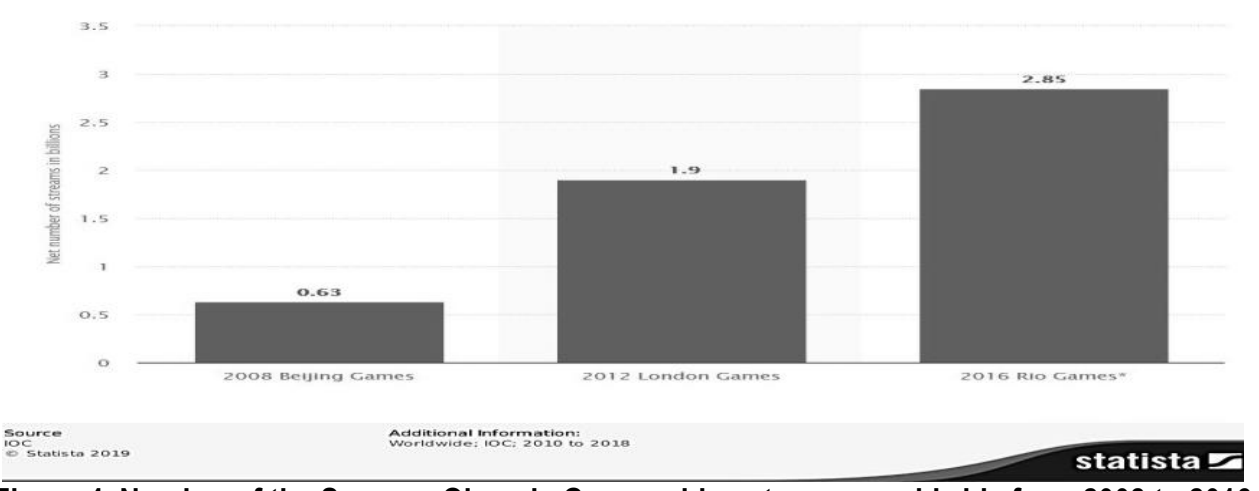

Figure 4. Number of the Summer Olympic Games video streams worldwide from 2008 to 2016 (billions)

Source: developed by the authors based on (Statista, 2019d).

The statistical data of the Winter and Summer Olympic games indicates that the quantity of the viewers has grown on the Internet and reduced among the TV channels. What advantages does television have? They are not so numerous. Firstly, the television is mostly free of charge (excluding the additional content). Secondly, it has maximum coverage as there is a TV set in almost every house and every age group watches the television and it provides the possibility of the background view. In the case of rest of the things which television can provide, it does not have the advantages over the Internet. Recently, in general, the television watching fell in all the age groups besides the «65+ audience» that is now the most active TV viewer. The television loses mostly the young and active audience. The main reason is that the television is statically by its nature: program $X$ will be released at 5 p.m., and the program $Y$ will be in the air at 6 p.m. On the Internet, each program will be released at the time a viewer needs it, and in a volume he or she needs it. And with the development of high-speed Internet, it can be wherever one wants it: in public transport, a car, etc. As can be seen on both sample of the TV broadcasts of the Winter and Summer Olympic Games for the last ten years the quantity of the TV audience falls. But the interest of people about the Olympic Games is still big, but it has shifted to the Internet and online space. The GlobalWeblndex 
(GWI) did an interview called «Sports around the world» among 90.000 internet users. Each day the online sports broadcasts become to be more and more popular, and people watch them more often on mobile devices. The interview showed that more than two-thirds of people with access to the Internet watched sports competitions online. Moreover, 2 out of 5 used the mobile device for it. "e-Media not only have made the information network much denser but also have extensively expanded it» (Enzensberger, 2015).

Most of those who watch online sports broadcasts are not sports fans of certain kinds of sport: people say that they watch different kinds of sports competitions. On average the interviewed people watch 4.1 kinds of sport and in Asia-Pacific and Latin America regions - 4.6. Traditionally it is considered that the men are more interested in sport than the women, but in reality, the difference is not very big. Almost $80 \%$ of the interview women all over the world reported that they watch the sport online or visit the competitions and games (See Table 1).

Table 1. People observing sports events in the different regions of the world according to their

\begin{tabular}{lcc} 
& gender & \\
\hline \multicolumn{1}{c}{ Region } & Men (\%) & Women (\%) \\
\hline Asia Pacific & 58 & 42 \\
Europe & 56 & 44 \\
Latin America & 51 & 49 \\
Middle East \& Africa & 61 & 39 \\
USA \& Canada & 53 & 47 \\
\hline
\end{tabular}

Source: developed by authors based on (Facebook IQ, 2019).

More than half of the users with access to the Internet reported that they watch the broadcast and reviews of sporting events on different devices at least once a month. More than one-third of the respondents use mobile phones, less than one third use the laptops for these purposes. Almost each fifth internet users watch sports competitions in the social nets, and among the sports fans, the percentage of these people is twice bigger (Facebook IQ, 2019). The IOC responded to the digital reality by launching the cross-platform Olympic Channel in 2016, aiming to increase the audience with a focus on young viewers. It is an all-year 24/7 channel broadcasting in 11 languages. The channel broadcasts sports programs, news, live coverage of main events, and provides additional information about sports and athletes. The Olympic Channel can be accessed from anywhere through mobile applications running under Android and iOS, as well as at olympicchannel.com. The 2018 PyeongChang Olympics were the first games broadcast by the channel. Besides, the live stream was expanded to YouTube and can also be accessed through a special Google search query (Olympic Games. Olympic channel, 2018). Thus, the Olympic Channel is a certain challenge to mainstream sports TV channels. It is worth noting that mainstream TV channels, such as Sky Sports, CCTV-5, etc., also actively expand their online presence by creating official websites (Sky Sports official site, n.d.; CCTV-5, official site n.d.) and social media pages (Table 2). Table 1 shows the online audience of Sky Sports and Olympic Channel in popular social media, counted as the number of subscribers. CCTV-5, due to the specific policy of China, is represented in the national social media Weibo.

Table 2. The audience of the Olympic Channel and Sky Sports in social media (official pages)

\begin{tabular}{lcc}
\hline \multicolumn{1}{c}{ Social media, subscribers } & Olympic Channel & Sky Sports \\
\hline Facebook & 3.163 .528 & 11.520 .327 \\
Instagram & 267.876 & - \\
Twitter & 368.463 & 4.909 .103 \\
YouTube & 3.232 .973 & - \\
\hline
\end{tabular}

Source: developed by authors based on social media data as of 12.02.2019. 
The selective monitoring of the TV broadcast schedule, conducted from 15.12.2018 till 15.02.2019, on Sky Sports (Sky Sports, official site n.d.) and CCTV-5 (CCTV-5 official site, n.d.) showed that in both cases the most globally popular and profitable sports, such as football, basketball, tennis, etc., had the maximum air time. The second most popular sports are the national ones (for example, cricket and badminton), while Olympic sports (the winter ones in this case) are only in the third place, as they are not extremely popular when broadcasting outside the Olympics period. We would also like to note that sports TV channels focus on the performance of sports anchors, the TV program structure, infographics, as well as special news blocks and entertainment and sports programs to attract and retain viewers. The importance of entertainment and sports programs is due to the trend of perception of sports as a show. Accordingly, the Olympic Channel focuses mainly on Olympic sports. Here, the different goals of the mainstream channels and the Olympic Channel come to the foreground: the former try to attract the maximum attention at every second by appealing to already popular sports events. At the same time, the latter intends to attract the audience to the Olympic Games by promoting the involved sports. The general trait of sports organizations and TV channels is the absence of visible inertia and the active use of digital resources to achieve their objectives. Such diversity, in our opinion, has a positive impact on viewers who have the option to choose in a competitive environment. On the other hand, we can state that the struggle for viewers between the mainstream and new media is exacerbating. It should also mention that sports federations (the international and national ones), professional sports leagues and clubs also have their websites with detailed and updated information (FIS official site, n.d.; IBU official site, n.d.; ISU official site, n.d.), as well as pages in social media (Table 3 ).

Table 3. International winter sports federations in Instagram

\begin{tabular}{lcc}
\hline \multicolumn{1}{c}{ Federation } & Publications & Subscribers \\
\hline FIS Cross-Country World Cup & 1.492 & 52.836 \\
IBU Biathlon World & 2.492 & 80.495 \\
ISU Figure Skating & 1.267 & 165.410 \\
\hline
\end{tabular}

Source: developed by the author based on Instagram data as of 15.02.2019.

Many leading athletes are also active social media users (Table 4).

Table 4. Olympic athletes on Instagram (personal pages)

\begin{tabular}{clcc}
\hline Federation & Athlete & Publications & Subscribers \\
\hline \multirow{2}{*}{ FIS } & $\begin{array}{l}\text { Johannes } \\
\text { Høsflot }\end{array}$ & 731 & 324.995 \\
& $\begin{array}{l}\text { Klæbo } \\
\text { Jessica } \\
\text { Diggins }\end{array}$ & 1.175 & 108.227 \\
\hline \multirow{2}{*}{ IBU } & $\begin{array}{l}\text { Martin } \\
\text { Fourcade } \\
\text { Dorothea }\end{array}$ & 997 & 406.450 \\
& Wierer & 317 & 349.356 \\
\hline \multirow{2}{*}{ ISU } & $\begin{array}{l}\text { Javier } \\
\text { Fernandez } \\
\text { Evgenia } \\
\text { Medvedeva }\end{array}$ & 582 & 254.799 \\
\hline
\end{tabular}

Source: developed by the author based on Instagram data as of 16.02.2019. 
Tables 3 and 4 show examples from Instagram for sports federations and athletes, accordingly. Chinese athletes are active users of their national media Weibo; for example, the Olympic short track champion Wu Dajing has 5.27 million subscribers (as of 16.02.2019).

The data in Tables 3 and 4 visualize the interest in public pages shown by sports federations and athletes on the one hand and sports enthusiasts on the other. The latter sympathize with athletes rather than the federation the athlete represents (as in all the provided examples).

At the final step of our research, we analyzed the audience, i.e. sports fans in this case. Without doubting their grading into «those who prefer watching TV while lying on the sofa» and «the advanced ones who prefer digital media» (Kroon and Eriksson, 2019), we used the initiative criterion, conditionally dividing the sports fans into two large groups: the passive and active ones. The former simply watch live streams on TV (whether the traditional or online one) and share their emotions verbally only when meeting others in person. The latter actively use various virtual resources to express their personal opinions and discuss their favourite sports, athletes, or events. The sociological survey «The most common activity on the 'second screen' when watching the Winter Olympics». With the above-mentioned approach, the most indicative is the data of the sociological survey «The most common activity on the «second screen» when watching the Winter Olympics» (Statista, 2018). The survey included Winter Olympics enthusiasts and was conducted worldwide and online in the second quarter of 2017. As a result, the survey covered 30,755 responders aged 16-64. The question was formulated as follows: «When watching TV, what do you most often do with your other device?» and assumed several answer options. It was found out that:

- $\quad$ half of the responders $(50 \%)$ communicate with their friends online;

- $\quad$ every fourth responder (25\%) simultaneously with watching TV looks for additional information on the game events on the Internet;

- $15 \%$ of the responders actively share their opinion on the Internet on what they have seen.

Thus, even when watching a TV broadcast, a considerable number of viewers immerse in digital reality. Active fans, while «being at the avant-garde of the digital revolution» (Pearson, 2010), not only consume the information flow but also participate in its formation. The post author is not only one who is involved in the process of online discussion in open fan communities, but also all those who reply to him. "Sometimes a comment can cause a greater wave of discussion rather than the post itself» (Ivanova, 2011). Quite often, fans have more knowledge about their favourite sport or athlete than some sports journalists and share their knowledge, which makes their contribution to the information field even more valuable. Fan communities (not only the sports-related ones) are a separate discussion area of the research (Pearson, 2010; Waysdorf and Reijnders, 2019). Making no claims of deep and broad knowledge, it should note that in fact, traditional sports fandoms migrate from the real world into the virtual one, when not a stadium stand. However, a sports forum, blog, or social media page becomes the «strong emotional experience of the meeting spot» (Waysdorf and Reijnders 2019).

The advantages of the Internet are various. One of the main strong points is that there is the availability of the sender and recipient of the information, and also it is impossible to watch it as a background. The Internet provides many different points of view. However, in such circumstances, it is difficult to evaluate their objectivity, and there are many fraud and doubtful sources. Moreover, sometimes the information can be unreasonable. So, one should carefully choose the sources of the information on the Internet. But besides it, the Internet gives the possibilities to set dialogue and take part in it and it makes an internet user be more active participants of the communication process. In the net, a person becomes to be a source of information that is not possible on the television. And it means one very simple thing - in each media a person loves himself/herself. People want to get to know something more about them and share that with the world; they want to create something with less of the efforts. The inspiring videos about a basketball player overcome a fail, an athlete who told a fiery speech about the mentors on an award ceremony and the sport as a source of life the knowledge help people to see the simple personalities in 
the sportsmen and something more than a competition in the sport. The Internet has strong possibilities for two-side communication. As a principle, new means of mass communication, it has such characteristics as interactivity, openness, lack of time, and space restrictions and virtuality. For observing the sports competition on the Internet, a person does not need to be in a certain place at a certain time. The only thing that a viewer need is to have the device - a laptop or mobile phone - and access to the Internet that is not also a problem with the high-speed mobile Internet. In the nowadays high-speed life it means flexibility and freedom for a user. It is not a secret that the news of any kind appears on the Internet much faster than on TV. People shoot videos and take pictures and put them into social media, and with the help of social activity functions, they are shared all over the world in a short period. Besides it, the Internet gives the possibilities to a user to buy the tickets for sports competitions and all the sport-related products: clothes, books and sports equipment, etc. As a result of the research, we could propose the following conceptual model of professional sports representation as a media product on the example of the Winter Olympics (Figure 5).

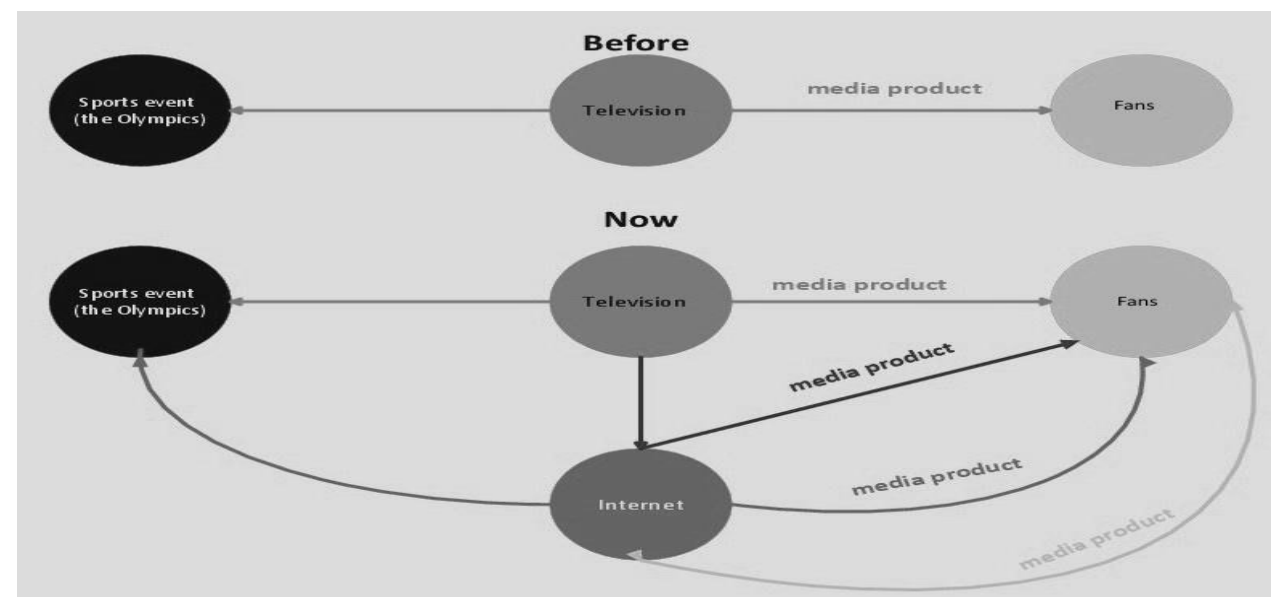

Figure 5. The conceptual model of the professional sports representation as a media product (on the example of the Olympics)

Source: developed by authors.

It should note that the growth of the number of information sources in sports communication is primarily due: to the creation of the official websites of sports TV channels; promotion and high-quality filling of the official websites of sports organizations, federations, clubs; their appearance in social media; the personal activity of athletes in social media (Twitter, Instagram, Facebook, YouTube). Social network analysis can also be used as a big data processing tool. In the social area, it can be applied to study recognition of certain ideas, concepts, and images, as well as to identify their distribution channels (Polyakova et al., 2019). We agree that thanks to technological advancements, media, and technology not only have spread into social life but have also become more diverse and sophisticated (Ytre-Arne and Das, 2018). Compared to traditional broadcasters, online media have a huge potential: «people obtain not only virtually unlimited access to resources but also a tool to form a public opinion... e-Media provide a unique channel for publishing and communicating, which excludes any bureaucratic intermediaries» (Ivanova, 2011). In the cyberspace, users can «easily find, create, and share their knowledge with others beyond their spatial, social, and time limits» (Grenz and Eisewicht, 2017), i.e. the mainstream audience of the elite sports in the current reality is not only the consumer but also the producer of sports content. Stating the complication 
of communicative links, we draw attention to the conflict of interest and the acute struggle for viewers between the television and online streaming. The reduction in the number of TV viewers does not mean that «people watch fewer events, but that they have migrated to online platforms and the permanently expanding array of available streaming services and applications» (PWC, 2017). Future forecasts predict «the death of universal broadcasting» (The future of sports, 2015). However, the TV will not vanish within the nearest decades, but more probably will find a balance with online media and occupy its once-dominant place in the reality of multiple screens. Besides, television traditionally acts as a certain element of relaxation, when one does not have to hurry anywhere and can enjoy watching his/her favourite sports event. Therefore, it is not so easy to abandon it as it may seem at first sight.

Conclusions. In the 20th century, the sport had gone out of the frames of the separate states. It had turned to be the global public phenomenon that takes an important part in the physical moral and spiritual culture of almost all humanity and in the establishing the humanitarian relations and mutual understanding between different countries and peoples. The development of new media technologies and impressive growth in broadcasting rights revenues have heralded an intensification of economic ties between sports and the media, clearly dominated by financial and commercial imperatives. Due to the globalization of media culture, sports have become a multimedia product for sale, and fans have become ordinary consumers. The commercialization of sports has become a dynamic global business environment and has created a great sporting goods economy. Professional sports today are colorful shows and multi-million audiences, big money, and big-league politics. Elite sports are a huge platform for the implementation of plans for individuals, teams, federations, as well as for commercial and even governmental plans. The popularization of sports is one of the main aims of all the sports federations, and they try to use modern means of communication and spreading the information to do it. The analysis of the research results identified the follows:

1. There is a reduction of TV audience number of the Olympics, against the background of a general decrease in interest to the Olympic Movement.

2. However, the number of online streaming viewers is rapidly increasing, including those using a «second screen». Outside the time of the Olympics, TV channels quite sparingly cover the Winter Olympic sports that are note extremely popular; so the main source of information on them is the Internet.

3. The IOC solves the popularization problems by not only sports-related means and social interest revival, but also by including itself into the broadcast process.

4. Both sports organizations and sports TV channels actively develop the digital space, thus, on the one hand, expanding the information field, and, on the other, forcing fans to choose, causing a conflict between the classic television and online streaming.

5. Athletes become media persons and often interest the audience more than the sports they represent.

6. Fans are involved in the process of sports, and sports-related content creation and fandoms grow and «immerse into the Internet».

As a result, the structure of the 'Elite Sports' media product has become rather sophisticated, and the number of communicative links and broadcasting opportunities of sports events has increased. The rampant evolution of mass media has caused a rapid increase in the options for watching sports events, as well as the number of people watching them around the world. Fans, mainstream, and new media are interested in sports broadcasts and content as much as professional sports are interested in their close attention. But the conflict of interest of the television and online channels causes a search for a mutual equilibrium and symbiosis with the industry of professional sports. 


\section{References}

Beech, J. (2007). Selling the five rings: The International Olympic Committee and the rise of Olympic commercialism. International Journal of Sports Marketing \& Sponsorship, 9(1), 62-64. [Google Scholar] [CrossRef]

Beech, J., \& Chadwick, S. (Eds.). (2010). The marketing of sport. (V. Bashkirova and M. Chernoglazova, transl.). Moscow: Alpina Publishers. [Google Scholar]

Biathlon World. (2018). Some changes at the IBU cup. Retrieved from https://www.biathlonworld.com/news/detail/somechanges-at-the-ibu-cup

Bieber, C., \& Hebecker, E. (2000). You'll never surf alone: Online-Inszenierungen des Sports. In J. Schwier (Ed.). Sport als populäre Kultur. Sport, Medien und Cultural Studies, Hamburg: Trend Sport Wissenschaft. [Google Scholar]

Boykoff, J. (2018). Riding the Lines: Academia, Public Intellectual Work, and Scholar-Activism, Sociology of Sport Journal, 35 81-88. [Google Scholar] [CrossRef]

Brown, R., \& O'Rourke III, D. (2003). Case studies in sport communication, Santa Barbara: Praeger. [Google Scholar]

Bryant, J., \& Raney, A. (2000). Sports on the screen. In D. Zillmann, \& P. Vorderer (Eds.). Media entertainment: The psychology of its appeal. Mahwah: Lawrence Erlbaum Associates. [Google Scholar]

Carriedo, A., Cecchini, J.A., \& Gonzalez, C. (2019). Soccer in the mass media: Examining the role of metaperceptions of goal orientation on spectators' moral functioning. Journal of Human Sport and Exercise, 14(3), 571-583 [Google Scholar] [CrossRef]

CCTV-5 official site. Retrieved from http://tv.cctv.com/cctv5/

Devlin, M., \& Brown, N. (2017). Using personality and team identity to predict sports media consumption. International Journal of Sport Communication, 10, 371-392. [Google Scholar] [CrossRef]

English, P. (2017). Social media boundaries in sports journalism: Individual and organizational gatekeeping in India and Australia. Asian Journal of Communication, 27, 1-17. [Google Scholar] [CrossRef]

Enzensberger, H. M. (2015). Building Blocks for a Theory of the Media. Logos, 2(104), 142-161. [Google Scholar]

Facebook IQ. (2019). New trends among the sport fans all over the world. Retrieved from https://ruru.facebook.com/business/news/insights/the-changing-profile-of-sports-fans-around-the-world

FIS official site. Retrieved from https://www.fis-ski.com/en/cross-country

Gabaston, P., \& Leconte, B. (Eds.). (2000). Sports et televison: regards croises, Paris: L'Harmattan. [Google Scholar]

Goldblatt, D. (2018). The Games: A Global History of the Olympics. London: Pan Books. [Google Scholar]

Goodyear, V., Armour, K., \& Wood, H. (2018). Young people and their engagement with health-related social media: new perspectives. Sport, Education and Society, 24(7), 673-688. [Google Scholar] [CrossRef]

Grenz, T., \& Eisewicht, P. (2017). Variants of Interplay as Drivers of Media Change. Media and Communication, 5(3), 5-14. [[Google Scholarl]

IBU official site. Retrieved from https://www.biathlonworld.com/

IOF official site. Retrieved from https://orienteering.org/ski-orienteering/

ISU official site. Retrieved from https://isu.org/figure-skating

Ivanova, E. (2011). Professionalization of New Media and Ethos of the Public Sphere. The Journal of Social Policy Studies, 9(2), 169-194. [Google Scholar]

Kroon, A., \& Eriksson G. (2019). The Impact of the Digital Transformation on Sports Journalism Talk Online. Journalism Practice, 13(7), 834-852. [Google Scholar] [CrossRef]

Lenskyj, H. (2000). Inside the Olympic industry: Power, politics and activism. Albany: SUNNY Press. [Google Scholar]

Mauro, M. (2020). Media discourse, sport and the nation: narratives and counter-narratives in the digital age, Media, Culture and Society. [Google Scholar] [CrossRef]

Olympic Games. (2018). Future games sports programs full of passion and excitement. Retrieved from https://www.olympic.org/news/future-games-sports-programmes-full-of-passion-and-excitement

Olympic Games. (2018). Olympic channel to broadcast Pyeongchang 2018 across India and Sub-Continent. Retrieved from https://www.olympic.org/news/olympic-channel-to-broadcast-pyeongchang-2018-across-india-and-sub-continent

Pearson, R. (2010). Fandom in the Digital Era. Popular Communication, 8(1), 84-95. [Google Scholar] [CrossRef]

Pedersen, P., Laucella, P., Kian, E., \& Geurin, A. (2017). Strategic Sport Communication. Champaign: Human Kinetics, Inc. [Google Scholar]

Pilar, P. M., Rafael, M. C., Felix, Z. O., \& Gabriel, G. V. (2019). Impact of Sports Mass Media on the Behavior and Health of Society. A Systematic Review. International Journal of Environmental Research and Public Health, 16(3), 486. [Google Scholar] [CrossRef

Polyakova, A.G., Loginov, M.P., Strelnikov, E.V. and Usova, N.V. (2019). Managerial decision support algorithm based on network analysis and big data. International Journal of Civil Engineering and Technology, 10(2), 291-300. [Google Scholar]

PWC. (2017). Perspectives from the Global Entertainment and Media Outlook 2017-2021. Curtain up! User experience takes center stage. Retrieved from https://kampanje.com/globalassets/alle-arrangement/media-business-2017-2021/globalentertainment--media-outlook-pwc.pdf

Reca, A. A. (2006). Issues in Media Product. Handbook of media management and economics, 181-201. [Google Scholar]

Sky Sports official site. Retrieved from https://www.skysports.com/ 
Smith, R. (2001). Play-by-play: Radio, television, and big-time college sport. Baltimore: Johns Hopkins University Press. [Google Scholar]

Statista. (2018). Second-screen behavior among Winter Olympics fans 2017. Retrieved from https://www.statista.com/statistics/587904/olympic-fans-second-screen-activities/

Statista. (2019a). Global TV audience/viewership of Olympic Winter Games 2010-2018 Retrieved from https://www.statista.com/statistics/531768/global-audience-of-the-winter-olympic-games/

Statista. (2019b). Number of digital video views Winter Olympic Games 2010-2018 Retrieved from https://www.statista.com/statistics/334119/digital-video-views-winter-olympic-games/

Statista. (2019c). Number of digital video views Winter Olympic Games 2010-2018 Retrieved from

https://www.statista.com/statistics/280502/total-number-of-tv-viewers-of-olympic-summer-games-worldwide/

Statista. (2019d). Number of digital video views Winter Olympic Games 2010-2018 Retrieved from https://www.statista.com/statistics/595336/olympics-number-streams/

Steen, R. (2013). Power play - sport, the media and popular culture. International Journal of the History and Sport, 30(18), 2234-2236. [Google Scholar] [CrossRef]

The future of sports. Broadcasting. How will broadcasting change? (2015). Retrieved from http://futureof.org/sports2015/broadcasting/

Waysdorf, A., \& Reijnders S. (2019). Fan homecoming: analyzing the role of place in long-term fandom of The Prisoner. Popular Communication, 17(1), 50-65. [CrossRef] [Google Scholar]

Ytre-Arne, B. and Das R. (2018). An Agenda in the Interest of Audiences: Facing the Challenges of Intrusive Media Technologies. Television \& New Media, 20(2), 184-198. [Google Scholar] [CrossRef]

Ванг Янь, Чанчуньський педагогічний університет, Китай

Олімпійські ігри як цифровий медіа продукт

Ця стаття присвячена аналізу динаміки розвитку економічних взаємозв'язків між професійним спортом та медіа за останні десять років. Автори зазначили, що стрімкий розвиток нових технологій та спалах пандемії COVID-19 значно впливають та посилюють взаємозв'язок між спортом та медіа. До того, систематизація наукових напрацювань 3 означеної тематики свідчить про необхідність розширення уніфікованої термінології для розгляду професійного спорту як медіа продукту. Таким чином, доцільним є проведення подальших досліджень для висвітлення особливостей швидкоі еволюції спортивних медіа. Метою даної статті є визначення закономірностей, які формуються в комунікативному середовищі елітного спорту. Предметом дослідження є спорт як продукт, об'єктом - розважальні спортивні продукти у ссрері медіа. Олімпійські ігри представлено як міжнародну спортивну подію, що включає в себе ряд спортивних змагань. Методологія дослідження заснована на аналізі статистичних даних відкритих джерел інформації та емпіричних матеріалів (офріційні сайти спортивних організацій і телевізійних каналів, а також сторінки в соціальних медіа). Відповідно до мети дослідження, авторами проаналізовано цільову аудиторію спортивних подій; спорт як джерело інфрормації; мейнстрім та нові медіа. Результати дослідження дозволили визначити головні напрями фрормування інформаційного простору навколо досліджуваного об'єкта. Автори приходять до висновку, щодо ускладнення структури «Елітного спорту» як медіа продукту. До того, встановлено, що комунікаційні зв'язки та можливості трансляції спортивних подій мають зростаючу тенденцію. За результатами дослідження запропоновано концептуальну модель, яка ідентифрікує профресійний спорт як медіа продукт. Результати дослідження можуть бути корисними для визначення основних напрямків мейнстріму та нових медіа у досліджуваній області. Крім цього, отримані результати бути корисними для журналістів, блогерів, менеджерів та представників влади.

Ключові слова: цільова аудиторія, комунікація, поширення контенту, професійний спорт, спортивна подія.

Manuscript received: 27.01.2020

(C) The author(s) 2020. This article is published with open access at Sumy State University. 